\title{
臺灣次高山彙に於ける氷河地形硎究（第 $\mathrm{I}$ 報）2
}

\author{
鹿野忠 雄
}

\section{A. 圈谷地形及び堆石堤地形（承前）}

圈谷 8, 9, 10 次高主峯の南面㥀下 $1000 \mathrm{~m}$ に及ぶ大急崖をなして居り， 之れより西南に連瓦しバットワノーミン山に至る山稜は次高主峯より約 500 $\mathrm{m}$ 近い比高を表して急落して居るが，其の廣い山稜上西面の科面に 3 個の小 カールを認める事が出來る。各图谷は形態決して一樣でないが，何れも西微 北に開口し圓形に近く長さ幅共に $150 \mathrm{~m}$ 位と目測せられる。小圈谷なるため 崖錐による埋浚と破壤變形の程度著しいが，注意して觀察する時は次高山頂 よりる望見し得られ，其の高度は約 $3500 \mathrm{~m}$ と推測せられる。

圈谷 11 之れは前 3 者と同じく次高主㧛より酉南に連る山稜上，几ジトフ 山(35 I Om ) の北部に存在するもので東面に開口し, 高度約 $3400 \mathrm{~m}$ 队外, 其の 形狀は扁本なる圆形を呈し幅約250-300m と思はれる。

圈谷 12 前記ルジトフ山の南に於て東面するI圈谷がある。大さは圈谷II と大差なく，高度は約 $3470 \mathrm{~m}$ 內外と思はれる。此の 2 個の圈谷は破壤又は崖 錐に充塡せられ，可なりに變形して居るぶ，矢張り圈谷と認む可きものと思 はれる。而してシカヤウ社よりの登山路の途上, シカヤウ大山 $(3333 \mathrm{~m})$ 附近 よりる注意すれば之れを認める事が出來る。

圈谷 13,14 前記圈谷の南に於て份 2 個の圈谷が存在する。郎ちルジトフ 山の南に位置するパガン山附近に認められ，何れる北微東に開口し，其の幅 は約 200-300m，高度は凡そ3500m と思はれる。此の 2 圈谷は共に何れの地 點よりも望見し難く其の地を踏んで初好て知り得るものである。 


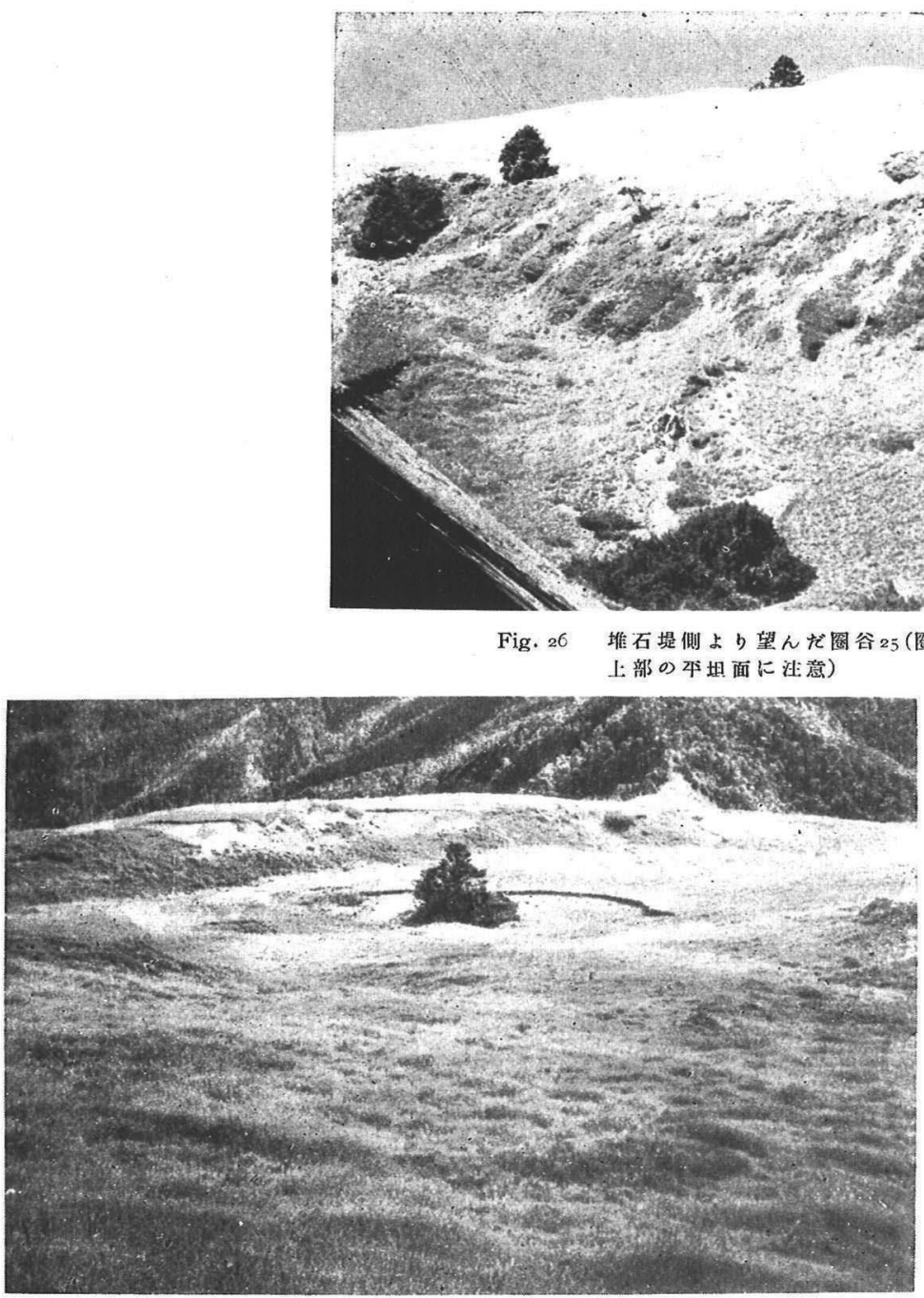

Fig. 27 圈谷 27 の 圈谷底々堆石壦

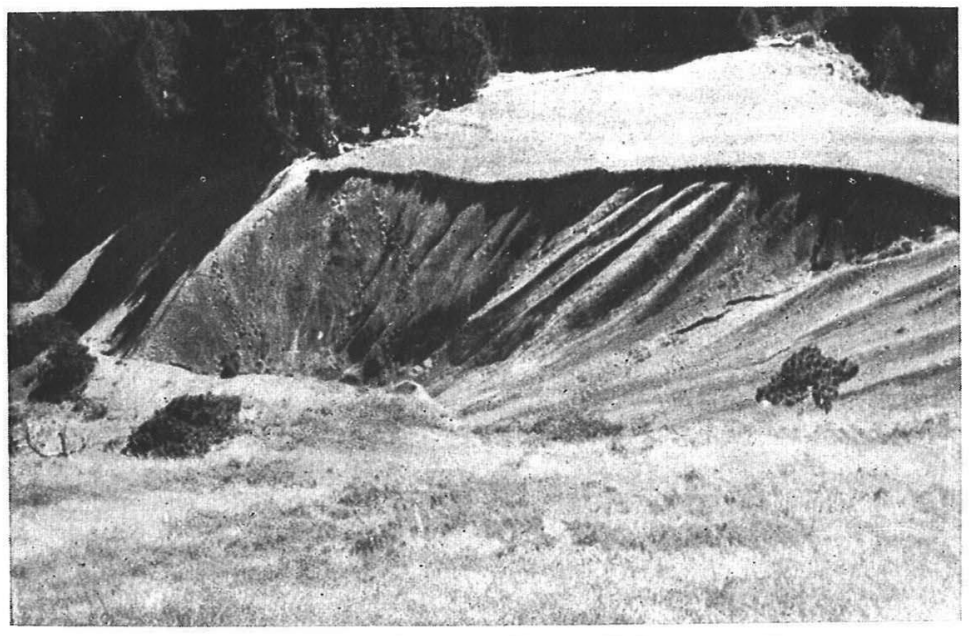

Fig. 28 圈谷壁上より望んだ圈谷25の一部 


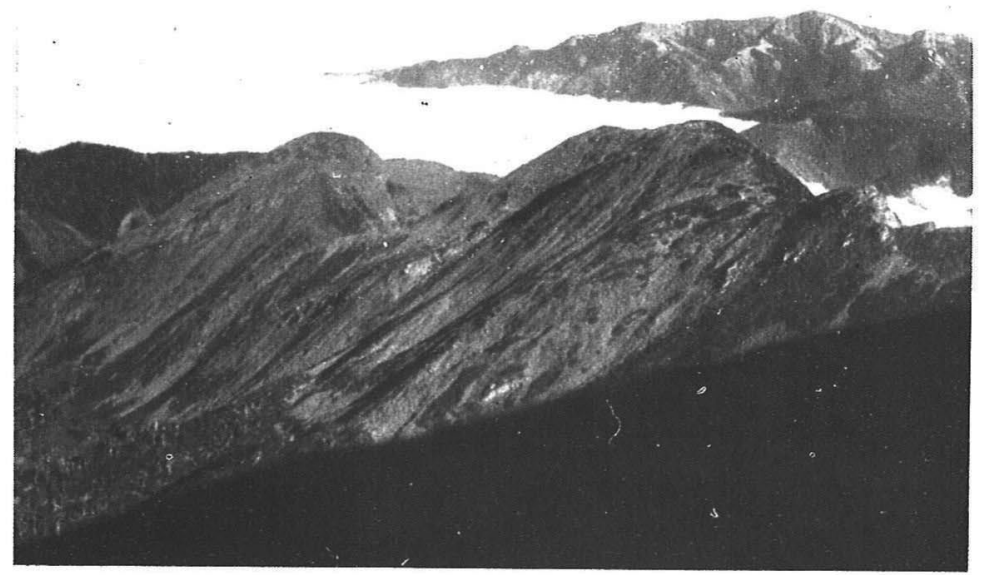

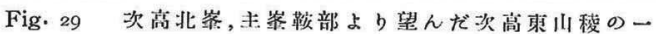

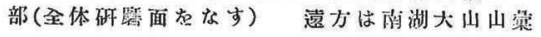

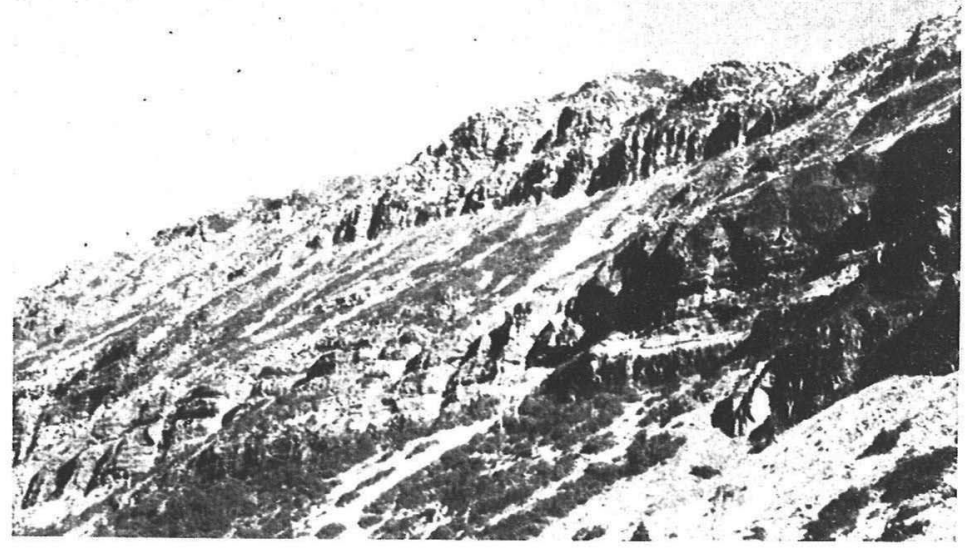

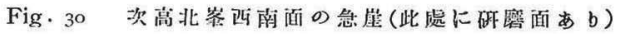

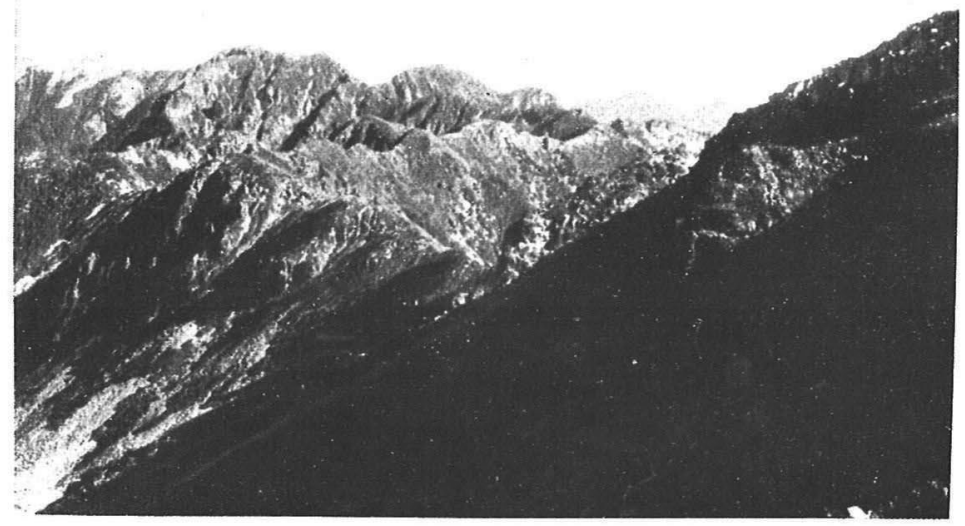

Fig. 3x 次高北䕓, タラクッシャ山(四中最高卙)間 山稜上に連立する圆顶突起 
圈谷 15 前述せるが如く, 次高主峯東北面カール之次高北峯北面カールは 次高北峯の東北に於て相接し，Iのアレートを挗んで居るが，此の圈谷I 第15圖の如く其の北微東に位置し, 前記 2 䍖谷と三角形の各邊に於けるが如 き關係にある。崖錐には可なりに埋的られて居り、ニヒタカビャクシンの籍 に被覆せられては居るが，要するに淺き圈谷と推定せられるるのであつて， 其の形狀楕圓形に近く, 幅約 $150 \mathrm{~m}$, 長さ約 $200 \mathrm{~m}$ 餘と思はれる。而して北東 に開口し其の高度は約 $3700 \mathrm{~m}$ と思はれる。

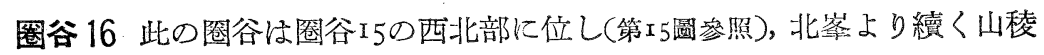
が西に突面を向灣入部の東面にあり, 東に開口, 其の存在は圈谷壁の一 部に崩落した大崖錐が雪溪と見まがへる程白色を帶びるため，次高東山稜， 遠くは南湖大山方面よりも其のカールをる事を確認し得られるものである。 而してキャワン溪のI支流は此の圈谷の直下に食ひ大つて居るが, 其處には 明瞭なる不連續線を認める事が出來る（此の溪谷は其の下流に於て次高主峯 東北面圈谷の直下に發したるキャワン溪本流に合流する)。其の形狀々略ぬ 牛球形に近く, 長さ幅共に $300 \mathrm{~m}$ 內外, 著しい崖錐に埋められ變形しつ〉あ るが，夫れにも拘はら机圈谷壁を筧ふ事が出來，圈谷なる事は疑ふ餘地がな い。其の高度は約 3650 mであらう。

圈谷 $17,18,19,20$ 圈谷 16 の東北に接し, 北東一南西の方向に連宜して夕 ラクッシャ山に續く山稜の東側に東面する小圈谷列を認兴事が出來る。郎 ち此の圈谷I7一20が夫れであるが，之等は何れる其の長さ幅共に IOOM 內外 の小なるるので, 其の底子淺いるのと推測される。崖錐は著しく其の底を埋 めて居り, 又ニヒタカビャクシンの箠に被は礼ては居るが, 圈谷壁は比較的 明瞭である。而して其の高度は約 $3600 \mathrm{~m}$ 內外と思は礼る。之等の圈谷は其の 大さの小形なると，變形せると，又樹木に被はるっためとにより一見其の注 
690

䴧 野 忠 雄

意を挽れ易いものであるが，次高東山积より注意すれば明膫に看取し得られ るものである。第33圖は次高主峯東北面图谷の下端より撮影したものである。

圈谷21 タラクッシャ山より東南に續く次高山荤主脈の西側に，西北に面 して開口するるのであつて，著しく破壤せられては居るが，圈谷壁の存在に より图谷と認めて可なるものと思はれる。長さ幅共に $250 \mathrm{~m}$ 內外，其の高度 は約3550m と推测せられる。

圈谷 22 之れは前記圈谷2 Iの北東に山稜を隔てっ科に位置するもので，夕

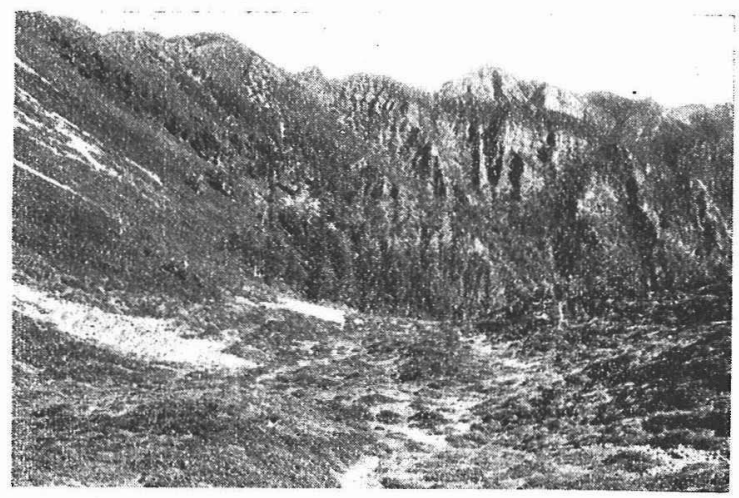

Fig. 32 欢高主萗山顶より下略したる東北面图谷底の一部

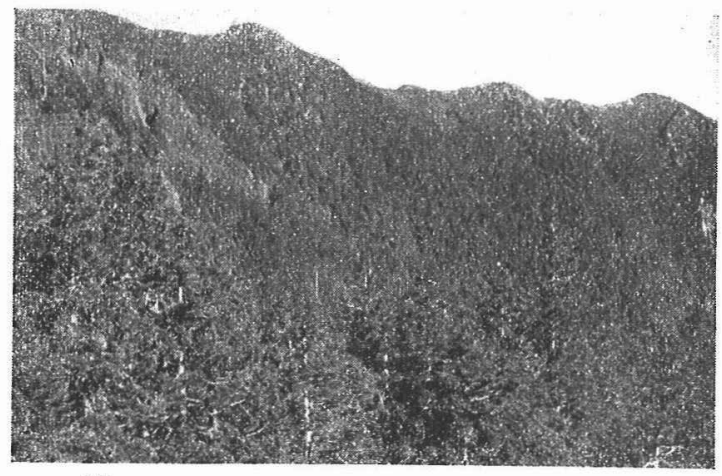

Fig. 33 次高主菜東北面圈谷末端より見たる圈谷 $17-20$
ラクッシャ山より東 南に南下する山稯の 東側にあり，東北に 開口して居る。其の 高度は圈谷2 2 と大差 なく, 約 $3600 \mathrm{~m}$ と推 測せられ，之れ又踐 い型に屬するとのと 思はれる。一部破壤 せられ，又は崖錐に 被はれ可なりに變形 して居るが, 圈谷壁, 堆石等の存在により 图谷と認を可き耐の と思はれる。長さ幅 共に250-300m 內外, 圈谷底の一部には二 
ヒタカビャクシンの籔や立木を見る。

圈谷23 之れはタラクッシャ山より東北々西微北に派出する山稜に抱かれ， タラクッシャ山の山頂北面に開口するものであるが，其の圈谷底に當る部分 は水蝕又は山崩れにより破壞せられ, 形態不完全, 所謂底拔けの圈谷に屬す るものである。而して其の圈谷壁は急峻な露岩の現れを絕壁として明瞭に認 められるが，底の拢けない前の图谷の大さを推定するに其の長さ幅300一 350 $\mathrm{m}$ 冈外と思はれる。

圈谷 24 之礼は次高主峯より大霸尖山に連互する主脈と, 桃山上り西走す る支脈との連結點, 即ちタクシャワン山の東北に位置するもので東北に開口 し，圈谷壁は略ふタクシャワン山より大鞾尖山に至る山稜と，ポテンシロン 山を經て桃山に至る山稜とによつて代表せられて居る。著しい崖錐により殆 んぞ埋沒し盡されて居るが, 牛球形を呈する圈谷壁の上端が崖錐の上端に露 はれ，堆石らしきものも認められ，更に其の位置が東北に開口する點等より 見て，圈谷の殆んぞ埋沒し去られたるのと見て間違ひない樣に思はれる。而 して其の北部よりの望見により其の變形前の圈谷の大さを推測するに, 奥行 幅共に $500 \mathrm{~m}$ 內外々見る事が出來る樣に思はれる。圈谷底は殆んど二ヒタカ ビャクシンメはニヒタカトドマツの森林に 被はれて居るが，其の高度は約 $3300 \mathrm{~m}$ 內外であらう。尚此の附近地層の走向は $\mathrm{N}_{5}{ }^{\circ} \mathrm{W}$, 傾斜は $50^{\circ}$ である。 此の圈谷は大霸尖山上よりる其の位置を窺ふ事が出來る。

圈谷 25,26 ポチンシロン山 $(3567 \mathrm{~m})$ 東斜面の一部に略々南北に並列する 2 個の圈谷を認める事が出來る。其の中北に位置し東に開口するもの, 郎ち 圈谷26はより形，且破壞變形著しいが，其の南にあり東北に開口する他の タの郎ち圈谷25は, 其の保存良好なる點と, 後述する特性を有するため非常 に興味媣く，且注意す可きものである。夫れが提供する種々の問題に就ては 
後章に於て記述する豫定であるが，此處には唯觀察して得を結果を有りのま 〉記述するに止める。

先づ其の位置を見るに，ポチンシロン山の山頂3567mより東に低下し, 更 に高距を增してタマラップ山 $(3558 \mathrm{~m})$ に至る間にI の鞍部が認められるが， 其處の高度は約3200mである。而してポチンシロン山頂より此の鞍部まで約 $360 \mathrm{~m}$ の比高を表して（其の水平距離は約 $1.5 \mathrm{~km}$ ）低下する科面には 2,30 小階段地を認める事が出來るが，此の圈谷は夫れ等の中 $3300 \mathrm{~m}$ 餘の高度にあ る階段地の小平坦面附近に形成せられて居る。

第35圖は此の圈谷の平面形，其の位置等を表す目的で作製されたるのであ るが，此の附近の觀察登山の都合上長時間を費す事が出來ず其の場で作製 したものでなく，下山後描いたものであるから，正確なるのではないが，其 の要領は表はされて居る。之れに依つて見るに，此の圈谷の上部に廣い本坦 面があり之れより $20^{\circ}-30^{\circ}$ の傾斜を以て下段の平坦面に落ちるのであるが, 此の圈谷は最初に其の下段の平坦面に出來初め，後に圈谷壁の後退に仍つて 上段本坦面のI部に食ひ达んだ事を推測し得る。其の平面形は圖に示す如く 殆んぞ圓形を呈して居り，圈谷最奧部中央の兩翼に更に耳の樣な大り达みが 認められる。此の樣に牛球形をなさず殆んど圓形を呈する事は夫秃自身一般 の圈谷と少しく趣を異にするるので，此の原因は前部に端堆石堤を控えて圈 谷の口部が閉塞されて居るためとも，一見考へられるが，此の堆積物の閉塞 によるは極く僅かであつて，圈谷の外壁自身が殆んご圓形を呈して居るのは 興味ある事と思はれる。今其の大さに就て見るに，其の幅 $150 \mathrm{~m}$ ，奧行 200 mであつて，露岩の現れた圈谷壁（最も高い所々最奐部中央であつて約 $50 \mathrm{~m}$ の高さを有して居る）は最奧部附近のみに見られ，圈谷側壁は 20 - $30^{\circ}$ の崖 錐(高さ20-30m)の斜面により被はれて居るのであるが，此の崖錐をなす物 
質は他の多くの图谷に於けるが如く，圈谷壁の風化破碎により其の直下に落 下して堆積した碎岩でなく，殆んど微細な砂粒より成つて居る事は又注意す 可きである。郎ち第 28 圖に於て見られる様に，此の崖錐斜面を水鹿が鸧け上 つた足跡があるが，獸の足跡が鮮かに印せられる程の均質の砂粒である。而 して此の白色を洮びた細砂な從來の經驗に仍るに殆んぎ氷河性遺物の認めら れる場所にのみ見られる處を以て見ると，或は氷成的と云はずとる，恐らく 氷河に關係あるものの如く考へられる。此の樣に側壁に當る部分は殆んぞ此 の砂粒に被は狆露岩を認める事が出來ないが，此の厚い堆積物を除けぼ其の 奥に图谷最奥部に於けるが如き岩壁を見出す事が出來る事と信ずる。

次高山夢に於ける他の图谷の岩壁は甚だしく崖錐に被はれ，又婘谷壁自身 も水期後の風化破碎に仍り變形し，氷期終結當時の岩面は刎淪，大體の原形 も其の保存に就て望多難い狀態にあるが，此の圈谷の岩壁な如何なる故か著

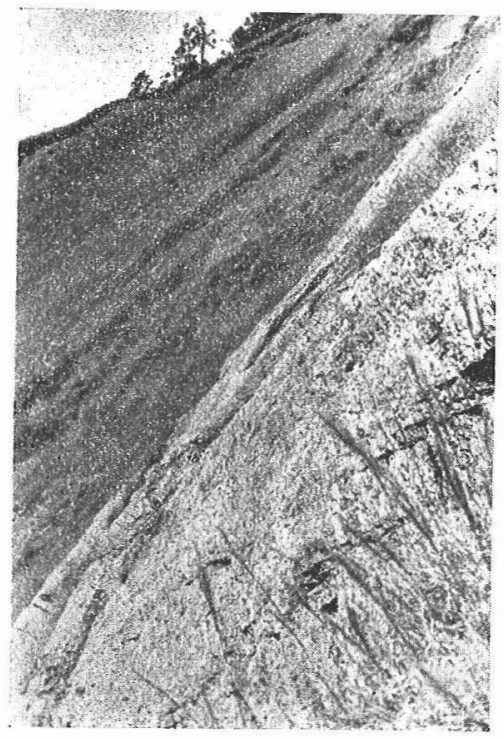

Fig. 34 圈公25の圈公壁の一部
しく保存良好であつて, 現在認められ る $60^{\circ}$ の岩壁の傾科は, 殆んぞ氷期終 結虽時の圈谷壁と見て大した間違ひな い觀を呈して居る。此の图谷壁を形成 しを氷期が極く最近のものとするも， 一般の常識より考へて斯くの如く保存 良好と云ふ事は明にエの预盾を示する のの樣に考へられる。而して此の岩壁 が果して氷創に仍るものが就て疑問 を懹くのは賞然の事とも思はれる。然 し乍ら深く此の圈谷壁を觀察するに, 第34圖の如く取物を以て切り下ヴを樣 
な部分もあるが，又一方に 第42圖に示す樣に凹凹や癖 狀突起, 又は小規模索階段 を現して決して直截面をな さず，極く小部分の平面を 取り上げてる其の中に不規 則なる凹凸を認める事等は 何を意味するものであるか。

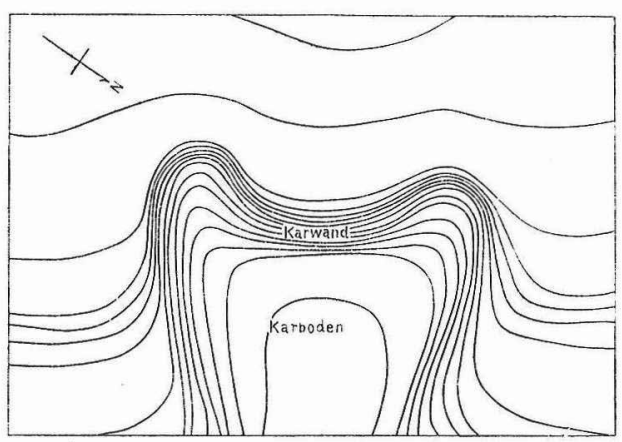

Fig. 35 圈公25の地形昌取羁 而して此の岩壁の表面を注意するに明に過去に於て研磨せられた外観を呈し て居る事は何を意味するものであるか。之等の岩面の多くは一部風化せられ (第36圖參照)，又は Scalling off が行はれて，明なる條痕を認める事は出來

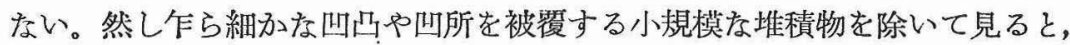
其の下には新鮮と云つてよい程の研磨 面が現れ，其の表面は氷河に關係ある らしき青白色の色澤を帶び，微細な又 は太き萷痕等さえが明膫に見られ，印 せられた彫清は水酸化鐵に染められて 保存は良好ではあるが，此の俼痕彫溝 が決して近代の形成に係るものでなく 氷蝕によつて初めて了解し得られる事 を表して居る樣に見える。

此の圈谷壁の岩質は砂岩と粘板岩と の互層である。而して其の走向は N65 Wであり，傾斜は $\mathrm{W}_{4} 0^{\circ}$ である。從つ

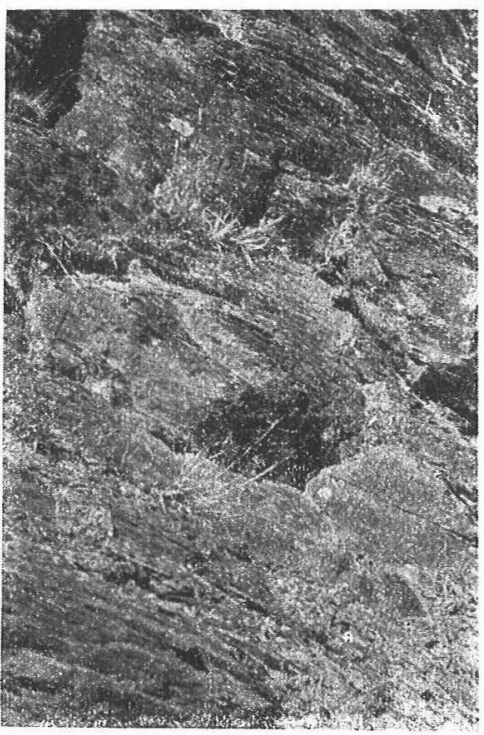

Fig. $3^{6}$ 图谷25圈谷譬一部の岩面 
て此の岩壁が成層面よりの剥離により生じをとは考へる事が出來ない。何故 ならば此の圈谷壁の岩面は此の地層を急角度に切斷して居るからである。又 此の岩壁面を山崩れと考へる事当出來ない。何故ならば此の附近の岩質は比 較的緻密堅硬であり，圈谷壁上部は急斜なく平坦面であり，且婘谷壁の下部 には堆積物は認められるが，其の外見よりして決して厚いものではないから である。又雪崩 (Avalanche)によるものとる考へる事が出來ない。何となれ ば，此の附近は雪崩が起る程多量の積雪がなく，圈谷壁の上部は平坦面で急 科なく凡そ Lawinenzug とは緣の遠い場所であるからである。而して更に岩 壁面が凹凸あり研磨せられ，份削痕ある事は，雪崩のみならす斷屒崖面に當 る当のでもない事を示して居る。從つて此の岩壁が氷蝕に仍るものである事 は略ふ肯定して可いと思ふのであるが，佮之れに俱ふ問題の考察に就ては後 述する事にしたい。唯如何なる理由に仍つて此の图谷が，斯く許り良好に保 存せられて居るか。此の問題の考察は重要な事と信ずるものではあるが，今 の處之れに對する probable な理由は, 材料の不足に仍り考入得ない狀態に ある。今後の觀察圭恃ちたい。

此の圈谷の末端附近には不規則な形狀を呈した堆石樣のものが認められ， （其の上にはニヒタカトドマツの森林が茂つて居る。）其の中には研磨せられ を礫を見出す事が出來，小流が此の堆積物を切つて下方へと落ちて居るが， 其の附近は又水蝕の疑ひが濃厚である。而して前記圈谷は更に下方に推移す るものではあるまいかとも考へられるのである。此の附近の地形は重姴な問 題を提供するものとは感じつょる, 蕃人を䍩導とする未開蕃境の山旅故, 種 その事故惹起し，充分の觀察が出來なかつたのは残念である。他日再び精查 の結果を待ちたい。

佾此の圈谷に就て注意す可きは, 此の圈谷底の高度が約 $3300 \mathrm{~m}$ を示し, 次 


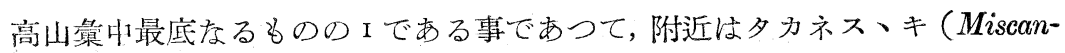
thus transmorrisonensis Hay.)の草原により被はれて居る。

圈谷27 ポチンシロン山より前記鞍部に落ちる東斜面は其の附近に於て $400 \mathrm{~m}$ を越える廣い山稜をなし, 圈谷 25,26 子此の附近の地點に位置するる のであるが, 此の2 個の啳谷の稍々東北に當り, 又別のカール狀地形を認め る事が出來る。此の圈谷はピヤナン社タイヤル族蕃人の狩獵小屋をるシムッ タの小屋(タッタク・シムッタ)よりポチンシロン山の山頂に至るには, 必ず 此の圈谷底を通過するを常とするが，圈谷底の掬ひ取りは極めて澁く，且著 しく岩屏や砂粒に埋められ，其の上タカネス、キの短生に被はれて居るをめ 一見圈谷たる事を見逃す程であり，圈谷としては極めて践い型に镯する当の と云へやう。

略々東西の走向を有する此の廣い山稜を傳ひ，シムッタ小屋を立つてポチ ンシロン山に向へば，鞍部より500m 足らすにして圈谷壁の斜面にかっり， 其處には茅戶の間に露岩の現れた階段狀の岩壁を認める事が出來, 其の傾斜 約 45-50其の高さは境界制然せぬため明には云ひ得ないが，20一-40m位の ๖のであらら。而して此の圈谷壁の直下より東北に $300 \mathrm{~m}$ 離れて第27圖に示 す如き堆石堤狀の地形が存在し，夫れは緩く突面を外方に向ける牛月形を呈 し，其の長さ約 $150 \mathrm{~m}$ ，高さは中央部最も高く $10 \mathrm{~m}$ 足らず（岩屃により充 塡されて居るから更に高いものであらう), 其の网烡は高さを減じて居る。此 の mound の表面は細き砂粒により被覆せられて居るが, 此の形狀を見れば 何人も之れが堆積物より成る事を疑はない事と思ふが，筆者は此の mound の內部が如何なるものより成つて居るかに就て充分に調べたいと思つたが， 時間の關係上的確なる材料を得る事が出來なかつた。而して其の時の觀察に 依るに或る部分は決して堆積物ではなく， solid な地愿の現れた岩盤より成 


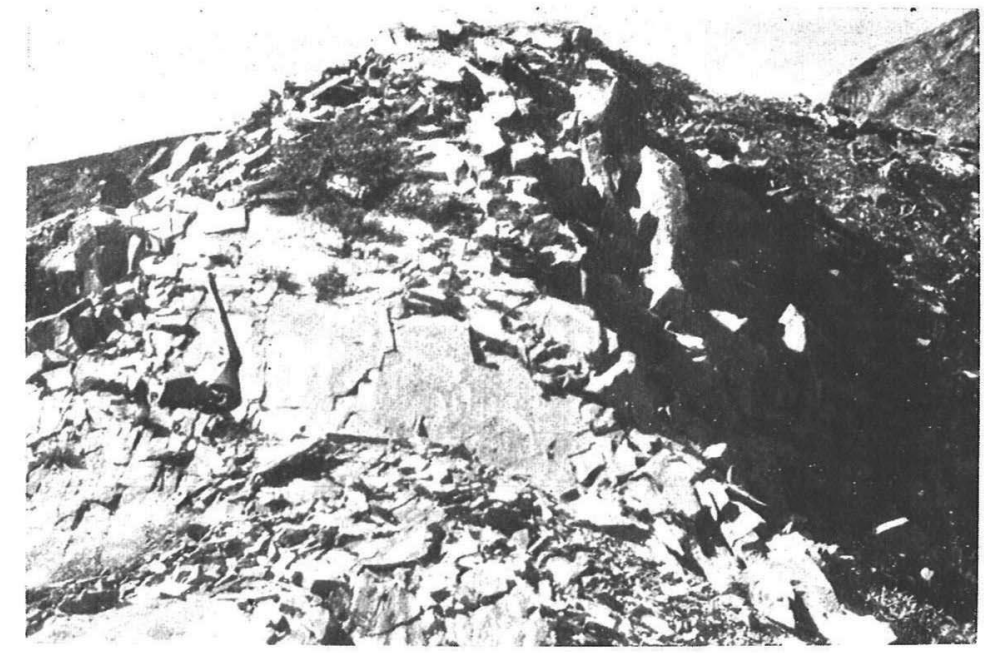

Fig. 37 次高北峯ょり 3 oom北の汕稄上圆顶突起に 殘行せる㗅留面

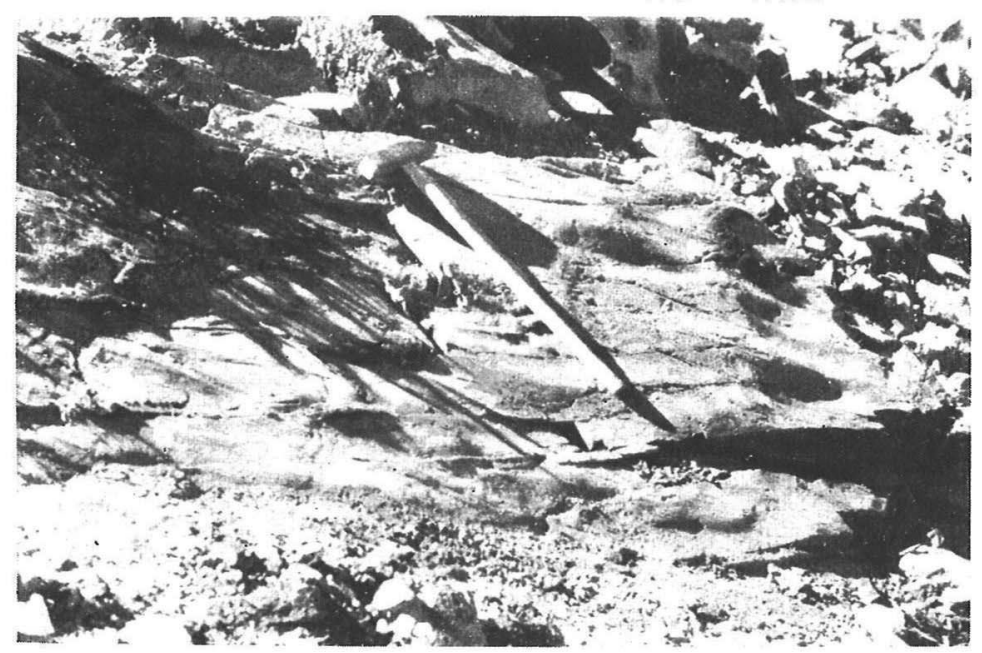

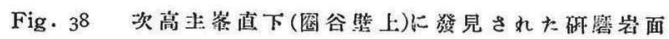

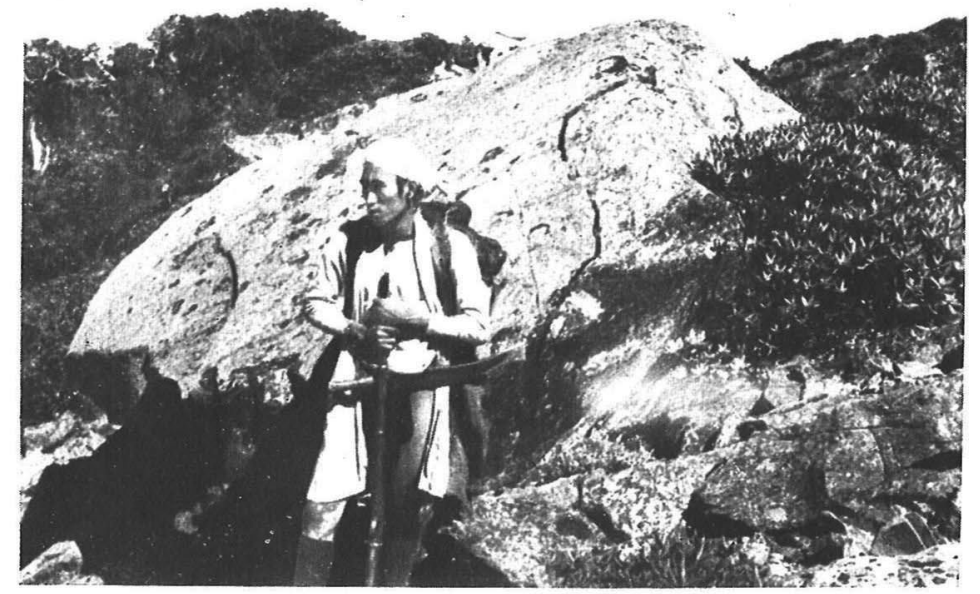

Fig. 39 次高北峑,タラタッシャ山閶山稄上に發見 


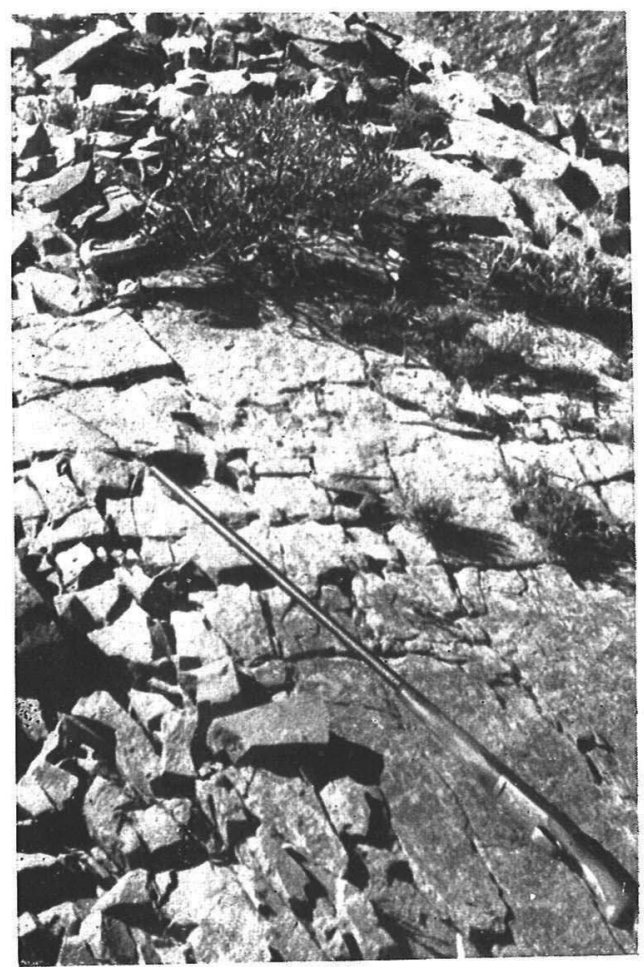

Fig. 40 第37圆に表はされた研䐴面の近景

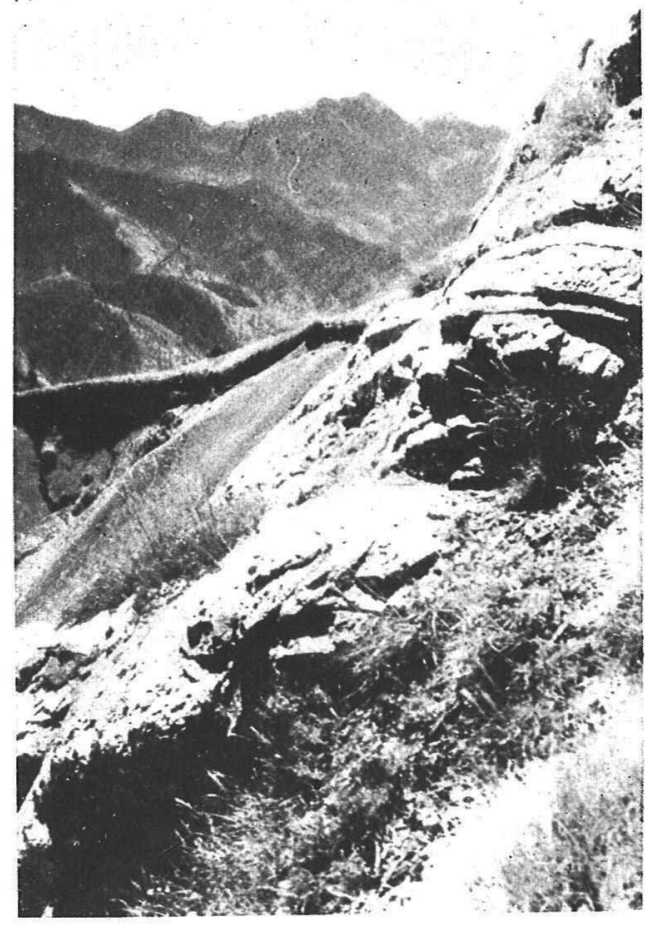

Fig. 42 圈谷 25 の圈谷壁の一部

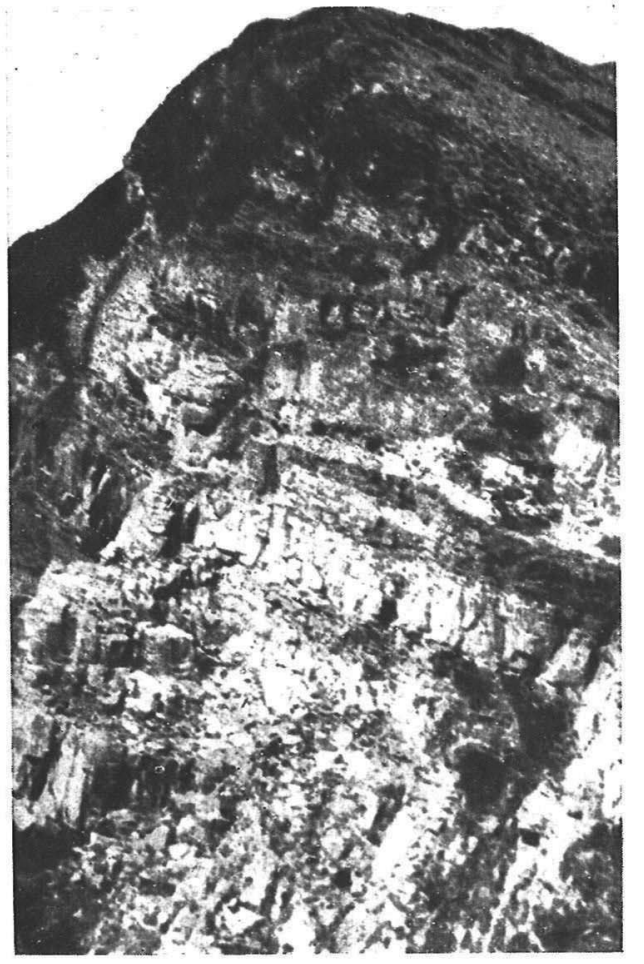

Fig. 4I 次简東山稜柬南佰急崖の一部

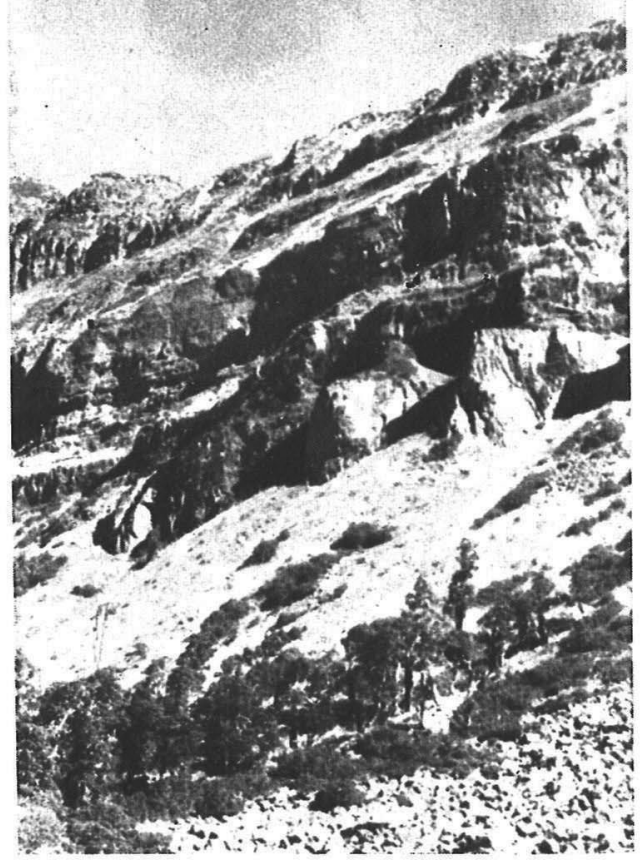

Fig. 43 次高北莑西南面急崖の一部 
つて居るかに見え，或は之れが堆石堤でなくして，Riegelの如ぎす或は他 の現在の知識にては不可知なるものとも思注れる點があるが，此の闍題に就 ては他日再び精查の䁱之れを報じたいと思ふ。

此の堆石堤樣の mound より图谷壁の直下との間, 即ち圈谷底極好て緩 き起伏を有する草原をなして居るが，前記moundに近き部分にI の圓形に近 き凹陷地があり(第44圖參照), 夫れはタカネス、キの短生に被はれ亦, 露岩を 認め得方細砂粒のみを露はして居るが，其の凹陷地が略及 $5 \mathrm{~m}$ の樑さを有す る處を見ると，此の圈谷底注少くとも5 $\mathrm{m}$ 以上の wasteにより充填せられて 居る事を推知し得る。而して此の四陷地の底には何等水を湛光て小池ををし を形跡がない點より見ると，大雨により一時雨水が此の凹所に溜つても間も 度く他に渗出する間隙が地下にある事思はしめ, 前記堆石堤狀のるのる或 は堆積物より成る畺の堆石堤ではないかとも思はせるが此の點は未ね゙明かで なく，今後の調查を恃ちたいと思ふ。

此の廣䓃圈谷底には處ふに草原の間より頭をもをげを岩石が覘いて居り， 其の形狀は何れる虽特な觀を呈し，圈谷壁最奥部の方向に緵く，其の外うに 急で，其の岩面には風化甚しきた奶制痕を認㧹ないが，今份圓噟された事 は立分に之れを看取し得，明かに之れは羊狀岩 (Roches moutonnées) が圈 谷底のwaste よりの埋没を挽れ，頭丈を摬かせて居るるのと觀察される。考 へ樣に依つては之れ等は漂石である樣にも思はれるが，此の羊狀岩の各々及 び圈谷壁の地層の走向が一樣に N $15^{\circ} \mathrm{W}$ であり，傾斜は $60^{\circ}$ 一 $70^{\circ}$ 交る點を考 へると, 此の岩は圈谷壁と連續せる岩面をなし從つて羊狀岩と見做して間違 ひないものと思はれる。第45圖に示したものは其のI例であつて，堆石堤よ りの距離 $100 \mathrm{~m}$, 粘板岩より成り, 其の走向 $\mathrm{N}_{1} 5^{\circ} \mathrm{E}$, 傾斜 $70^{\circ}$, 略及 4,5 呎 四方の大さ，草原より突出を部分视 2 吹位である。 
此の圈谷底の高度は約 $3270 \mathrm{~m}$ と思はれるが，此の附近の廣い尾根は波狀を な寸緵い起伏をなし，其の川の或るものは水を湛えて小池を作つて居るが， 之等の地形は矢張り水蝕に何等汃の關係を有するものと想像せられる。

圈谷 28 之れは前記廣い山稜の北面に開口するものであるが，かなりに破

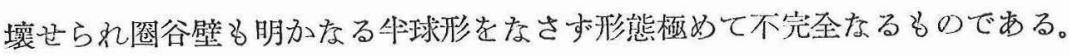
其の上崖錐の上には滑かな茅戶が゙えれを被覆して居るので，更に图谷とは認 め難いが，種くの點よりして总谷の破壤せられたるのと考へられる。

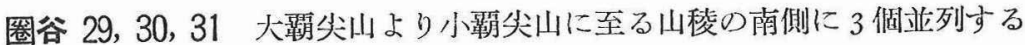
小カール列を認める 事が出來る。各圈谷 ○大さは奧行幅共に 150m 內外であり， 略从水本愿这有する 砂岩と粘板岩つ互詹 より成る圈谷壁を表 して居る。图谷壁は 一部破壤せられ，圈 谷底は崖錐に埋めら れて居るが，不完全 なる圈谷と認めて可 いるも思ふ。之等 の圈谷はタクシャワ ン山附近より望見す る事が出來る。

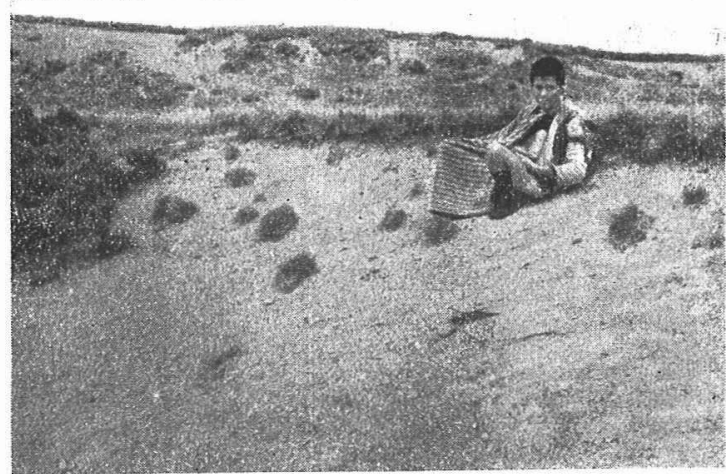

Fig. 44 圈谷27准石堤近くの回陷能の一部

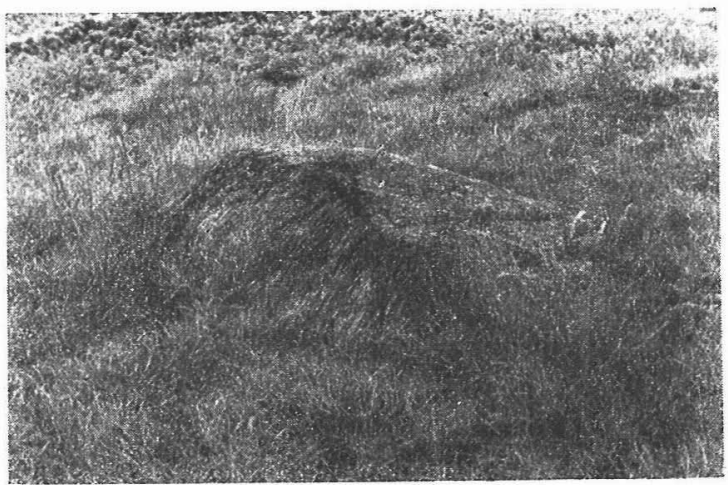

Fig. 45 圈谷27の罡谷底に發胃されれ年狀岩の一列 
圈谷 32 此の圈谷は大西䩦山と其の北に位通する3433mの峯とを連ねる山 稜の西側にあり，冏行幅共に約 $35 \mathrm{om}$ ，圈谷壁は原形を變形しつ〉あり其の

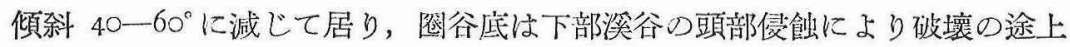
にあり，又上部より落下する崖錐により埋められつっあるが，其の崖錐の上

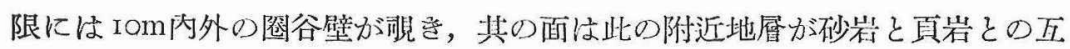
屓より成る水平屏なるため, 其の硬軟の差により階段㐩の斜面を現はして居 り，圈谷としての形態は現在不完全と認める可きるのである。

圈谷 33,34 1933年の探究は主として次高山量の主脈及び其の東面の支脈 に限られた。從つて大雪山を盟主とする西南の支脈の觀察は大いに餘地があ

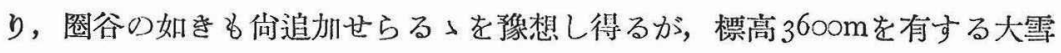
山の東面に 2 個の图谷を認める事が州來る。

\section{B. 水蝕硎磨面, 羊狀岩, 條痕其の他}

前述世る图谷並びに堆石堤の他に，多くの研嚰面，圓頂笑起，羊狀岩，條 痕ある岩面, U字谷, 膆谷, 漂石, 又矢張り水飿に關係あるものと思はれる ものに岩海(Felsenmeer)の存在を擧げる事が出棶る。此の章に於て夫れ等を

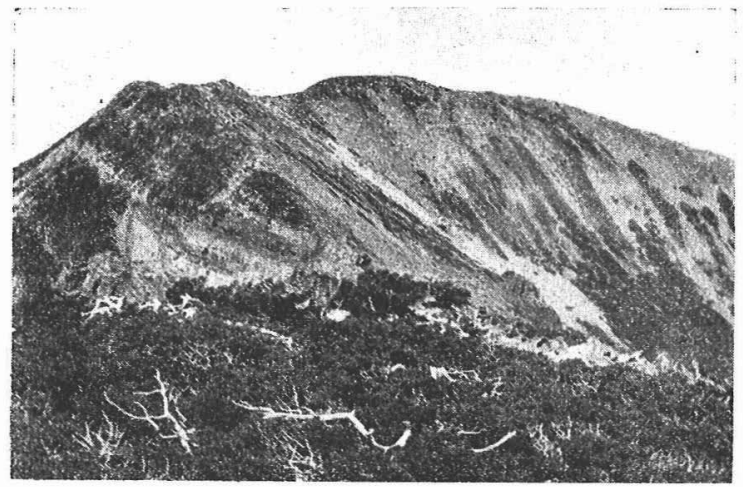

Fig. $4^{6}$ 東山稜上部より望んだ次宫主䒺車北面圈谷の一部

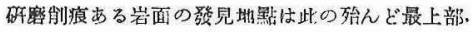

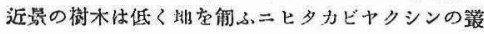

一括して報告する事 にするが，夫れ等の 多くは種類别に記載 するよりる，踏查の 經路に從ひ，各地域 别に記述するを便宜 と心得るので, 之れ に從ふ事にする。 次高主峯山頂附近 
次高主絴の山頂は諸方よりの遠聲によつても明なる如く，極めて圆滑なる劃 室線を表し，獨自の景觀を呈して居るが，後章にて詳述する樣に此の山頂附 近は土 の大なるルントヘッカーより成る圓頂突起と見て可いるのと思はれる。 然し乍ら廣い此の山頂上は現在此の種㞸面の露沙なく，一體に細砂粒により 被はれ，之れは現在東北面圈谷底に向つて匍行しつょある。此の次高山頂附 近に於て重要郝る撥見は，普通考へられる研磨面の位置より遥に上部に於て
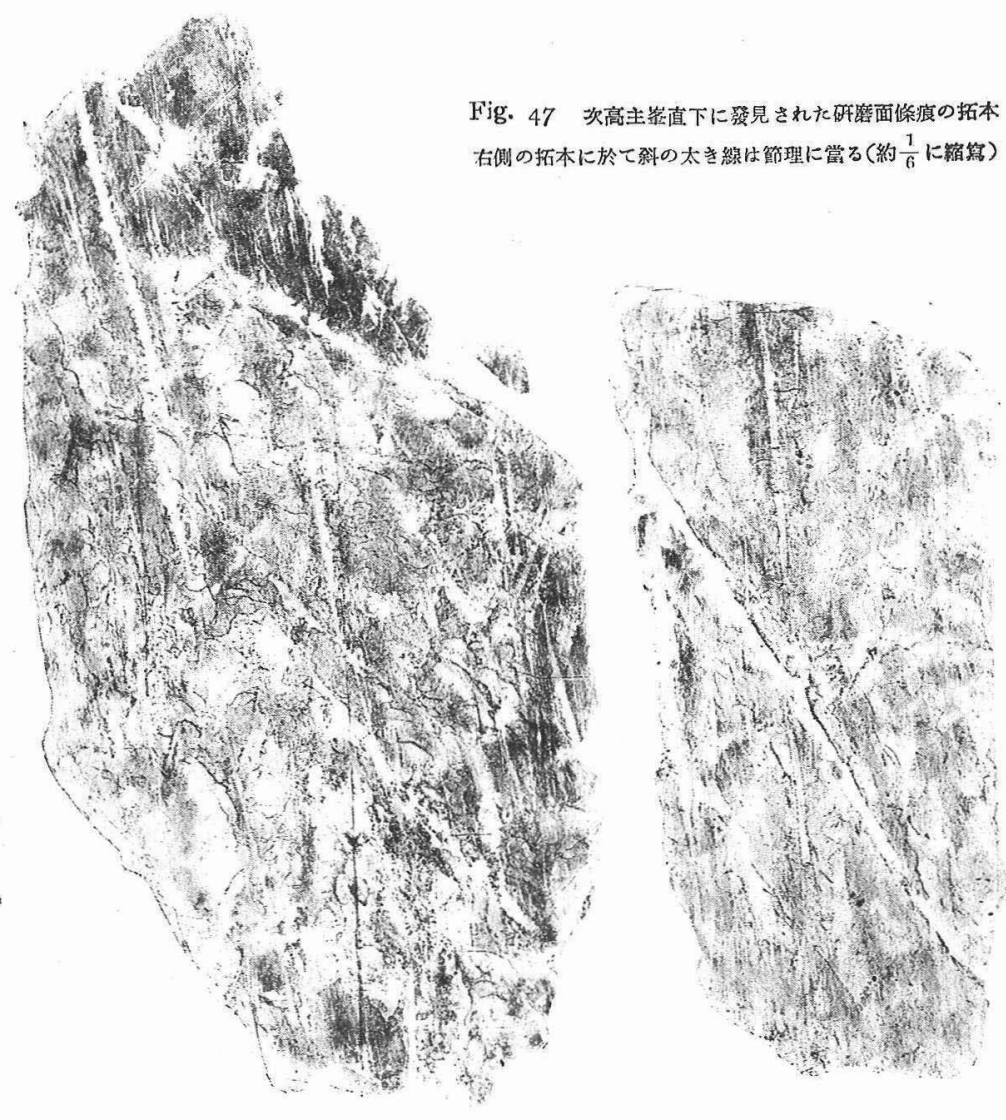
研磨削痕ある岩面を認め得を事實である。郎ち次高山頂上より東北に約 200 $\mathrm{m}$ 隔つを地點，而して其の比高は約 $30 \mathrm{~m}$ 下方，圈谷壁より上方の地點に岩屑 や砂粒よりの埋沒を炛れて牛疊敷程の岩面が露出し, 夫れは一見破碎轉位せ ざる連續的の岩䑾に見えるが，仔細に之れを觀察する時は夫れは過去に於て 岩盤が研磨せられ例痕を受けたるのが，其の後の破碎により母岩を離れ上方 よりずり落ちをるのなる事が明で, 其の附近の事情より見る時は最近まで土 砂岩首に埋められて居たるのが偶發的に露れたるのである事が察せられる。

第38圖は此の露出岩面を稍ぬ下方より撮影したものであるが, 土砂の埋涴 より露れたものである事は一見して明である。此の附近の土砂上には巳に强 風に痛められ低く地を匍ふニヒタカビャクシンが繁茂し, 又カハカミウスユ キサウ（エーデルワイズ）が花聧いて居るが夫れ等も此の寫訔中に表れて居 る。この岩質は堅硬なる砂岩であつて, 岩面は見事に研磨せられ, 微細䄈る
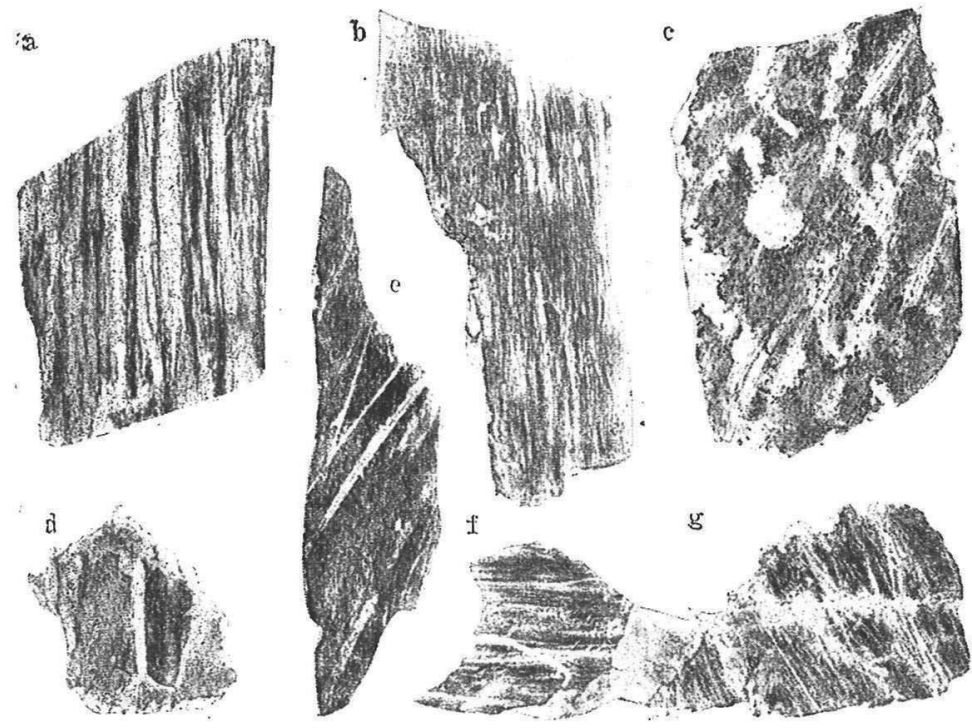

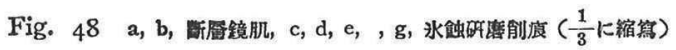


略々同一方向に向ふ條痕が認められ，又之れ以外に更に太き條痕が之れ等に 混つて認められ，夫れは約 $20^{\circ}$ 內外に於て異方向に走つて居る事が認められ る。而して更に上部に於て細く下部に向つて太くなり急に銳頭に終つて侧方 に外䏓を所謂標式的の nail-head 当之れを求めるに困難でない。第38圖の寫 真に於て畫面に略々平行するものは節理であるが，之れと科交するものが太 い方の條痕である。 又第47圖は此の岩面 の拓本で, 惡天候の 最中急いで竄したる のであるから良好な ものではないが，其 の大要を䇲ふ事が出 來ると思はれる。此 の露出岩面は崸に見 事なものであるが， 夫れは粘板岩の場合 と異り堅硬なる砂岩 质るためであらう。 是非此の岩面を其の ま〉保存したいる。 と思ひ，僅かに其の 一端を䅺本として打 ち取り持ち歸るに止 めたが，其の拓本は

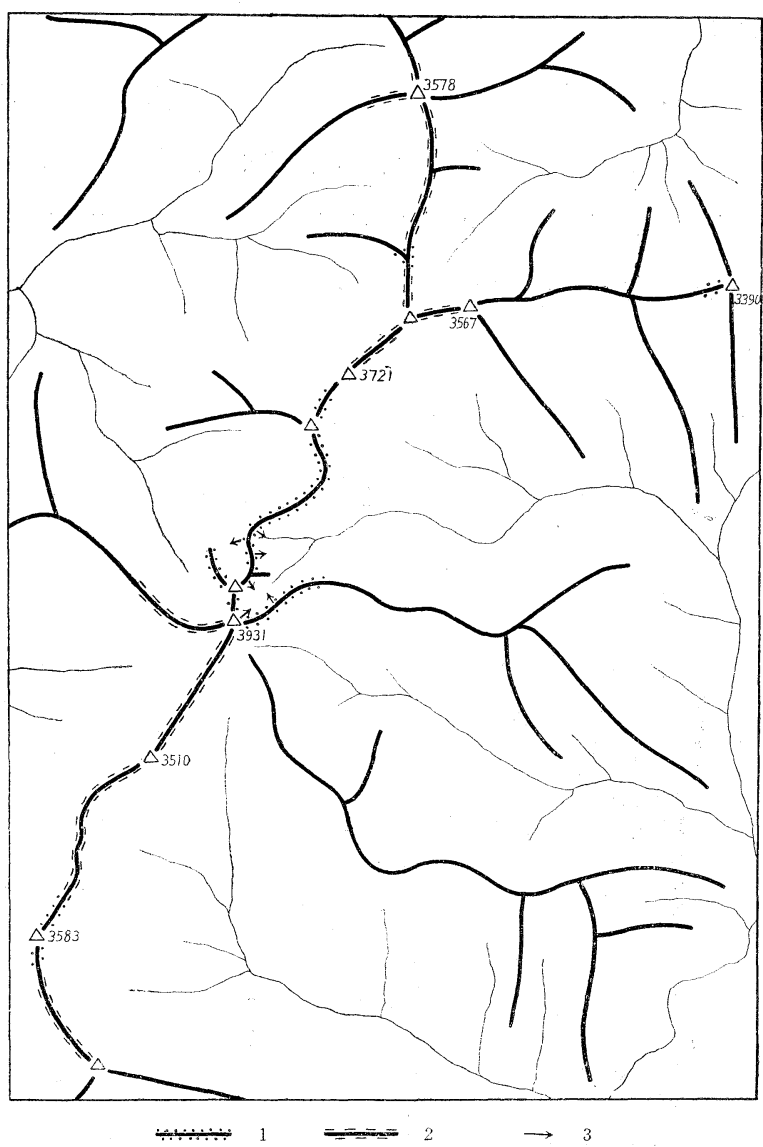

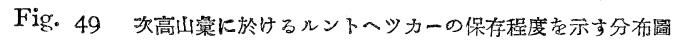

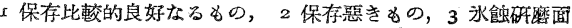
上に於ける條痕の方向を示す，(1: 150000) 
第48圖 dに表はされて居る。

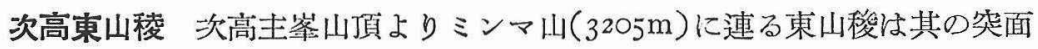
を北に向けて彎曲するが，山頂より $1.5 \mathrm{~km}$ の間は山稜東北に走り，夫れは山 頂より本均傾斜 $20^{\circ}$ を以て低下して居り, 其の山稜全體は又１のルントヘッカ

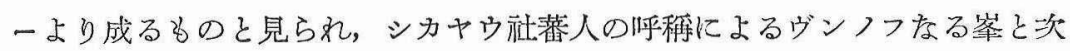
高主峯を合せて, 合計 3 個の大なる圓頂突起を認める牙が出來，之等の著し く圓滑なる山背は次高主峯上や北峯，或は附近の山稜上より著しく眼を莠く ものである(第29圖は次高主峯北蔡䩪部より撮影したるのである)。而して 大きく波狀を呈して低下する此の山稜の横斷面は第50圖に示す如くシカヤウ 大山上より最く好く籍ふ事が出來，又更に下つて支良節附近にて子觀㘹する 事が出來る。此の東山稯の北面は次高主峯東北面カールの側壁をなするのだ あるが，崖錐上に現れた圈谷壁の上部や圆滑な溜狀岩を戴く山积上は現在著 しい風化破碎が行はれ，一見岩海の狀態を呈し，或はニヒタカビャクシンや ニヒタカシャクナゲの占據する處となつて居るが，之等の間を丹念に搜索す る時は破碎せられた岩片の堆積の中に混じて，一面に研磨制痕ある岩㸝を求

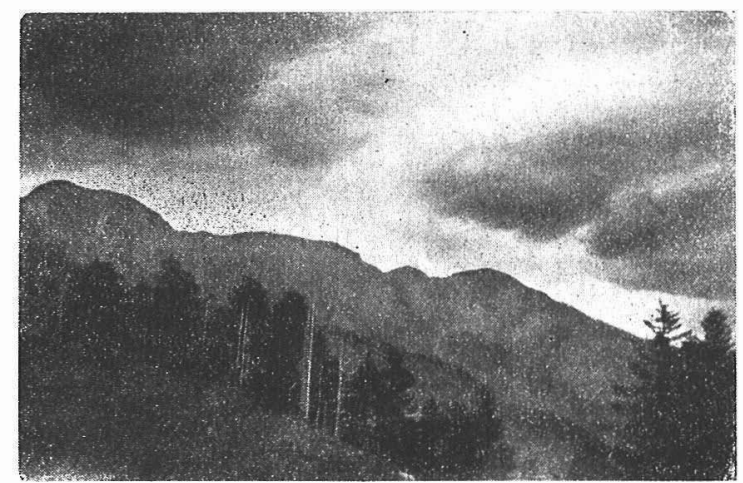

Fig. 50 シカヤウ火山附近より見たる次高東山崚， 左端の最高點は次高主暴
むるに困難でない。 又周圍の事情よりし て恐らく土砂の下に 岩盤が鿵れて居る榢 に思はれる地點を鍬 を以て掘り起せば， 其の下に比較的新鮮 に保存せられた前記 岩面（次高山媔直下 
の岩面）と略々同樣なるものを見出し得る事もある(第 48 圖 $\mathrm{f}, \mathrm{g}$ )。要するに 此の圓滑存る東山稜の高所は，昔時一の大なるルントヘッカーをなして居た 事は想像するに難くない。

此の東山稜の圈谷壁と反對の側, 郎ち其の西南の側は $300 \mathrm{~m}$ 近い略々直線 狀の斷崖（之れは後述するが如く後退しては居るが古い斷擪崖面に略々相當

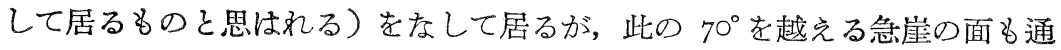
常の斷崖とは異つた觀を呈し，氷蝕の影響を考へられる樣に思はれたので， 筆者は此の采崖を牛ばロープに身を托して懸垂し調べて見たが，地層を急角 度に切る急崖面は益く此の感じを深くせしをるものがあつた。第4圖は此の 斷崖の上方の一部老表したもので，右手の斜面は圈谷底に續く科面である。

次高北峯北面圈谷の西面山稜 次高北方北面圈谷の西面の側壁は，次高北 峯山頂より西北に低下する小稜によつて代表せられるが，北峯山頂を含む此 の山稜全體は昔時に於て殆んどIの大なるルントヘッカーであつた事を推測 し得る。今此の山稜上の形態を注意するに，前述せる次高東山稜の場合と同 樣に極めて圓滑疾瘤の突起や波狀の起伏を示し，其の表面は風化破碎によ り破壞せられつっあるが，全體としての形態は左程變形して居ない樣に思は れる。而して此の山稜上には東山稜の場合の如く, 研磨削痕ある岩面の破片 が發見せられ，或は岩屃砂粒を除いた其の下には比較的新鮮な觀を呈する氷 蝕岩面が認められる(第48圖・は其の一例である)。

此の山稜の西南面は比高 $250 \mathrm{~m}$ 以上に及ぶ直線狀の急崖を示し, 其の平均 傾科は約 $70^{\circ}-80^{\circ}$ に及ぶが, 走向 $\mathrm{N}_{7} 0^{\circ} \mathrm{W}$, 傾科 $\mathrm{N}_{2} 2^{\circ}$ を示す。此の附近の地層 は砂岩と粘板岩の互層より成るためか, 階段狀の科面をなして居る。筆者は ロープに身を縛して，此の急崖を下降し急崖の途中にある階段地を精杳した。 此の觀察によると, 各階段地は其の廣さ極めて小なるため上部より轉落する 
崖錐は多量に溜る事が出來す，從つて多くの場合崖錐は厚くないのであるが。 此の崖錐の下には前述せる他の地點で發見したそ同樣な研砳制痕ある岩面を 見出す事が出來た。而して此の階段地より下部の急崖に落ちる崖際には崖錐 に被はれない露岩が現れて居るが，その面を注意するに第43圖に示すが如く， 極めて圓滑なる浪狀岩の觀を呈し，條痕は表面の風化により認め得ない場合 が多いが，過去に於ける水刢によるものである事は一見して明かである。第 30圖は此の急崖の斜面を西より撮影したものである。

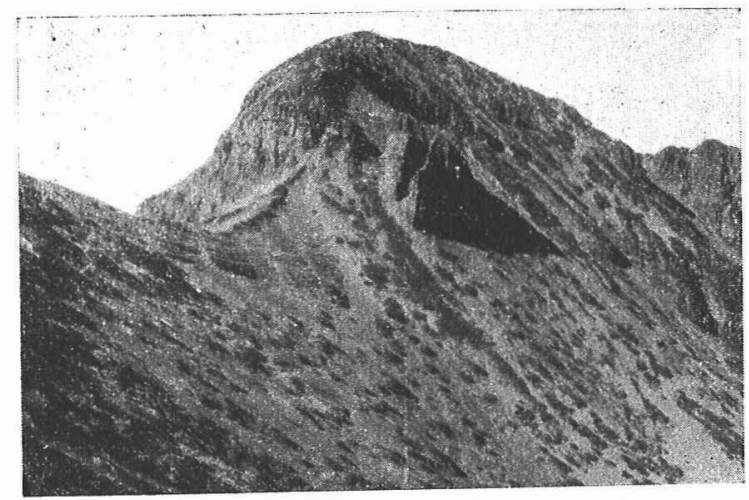

Fig. $5 \mathrm{I}$ 東侧より見たる次藏北傢，斯くの如く圆頂を品 し，夫れは全體ルントヘツカーと推測せらる

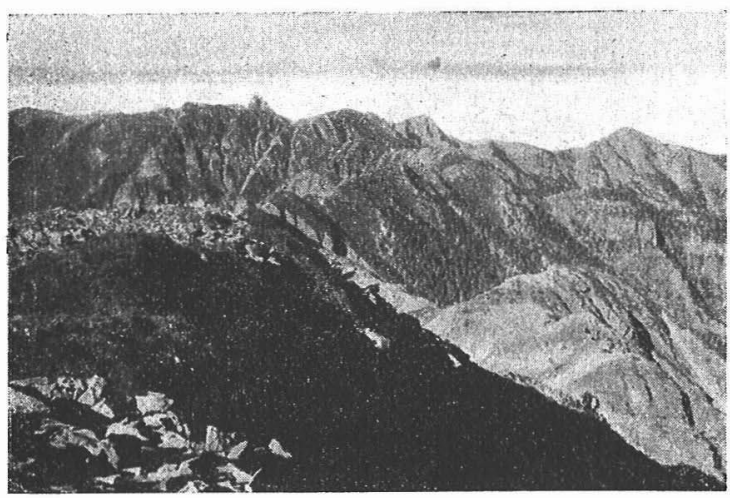

Fig. 52 次高北箪とタラクシッャ山の間の山稜, 平坦に して圆い緭狀笑起逨立す

\section{次高北峯よりタラ}

\section{クッシヤ山までの山}

稜 3930m の次高北 峯と $3800 \mathrm{~m}$ のラク ッシャ山は何れる大 なる圓頂突起を示し: （第51圖參照），過去 に於て大はるルン トヘッカーであつた 事を思はしめるが， 此の两者の間の山稯 は全體として極めて 平坦な山稜を示し， 稍々北方に向つて低 下するが其の比高は 200m を越えない。 而して注意す可きは 
此の山稜間に，圓頂突起が餘多連立する事であつて (第3匹圖參照)，其の大さ は一樣でないが何れも次高北峯やタラクッシャ山に比して遙に小さく，各圓 頂突起の起伏は 50mを越えす， $30 \mathrm{~m}$ 內外のものが多い。此の狹い山稜上に於 て第一に氣付く事は，之等圓頂突起をなす岩面は現在盛んに風化破碎が行は れ，縱走に際してもガラガラの岩片の堆積上を通過するに困難炎感ずる程で ある。而して之等の岩片の或るものの表面には明存る研磨削痕が認められ， 此の事實より見る時は，此の圓頂突起は過去に於てェのルントヘッカーであ り，其の後の風化により破碎せられたものである事を推知し得る。斯くの如 く圓頂突起は破壞せられ元の研磨岩面を保存するるのは殆んどないのである が，筆者は夫れ等の中で偶然に保存せられたるのが或は殘つて居ないるのか と, 此の山稜間を精査した結果, 比較的保存良好䒚る一例を次高北峯より北 $300 \mathrm{~m}$ の地點に於て得る事が出來た。郎ち第37圆は此の岩面を稍々遠方より 撮影したものであるが，之れによつてる見られる樣に圓頂笖起の或る方向の 岩面(此の場合に於ては北面)は研磨せられて居る事が明かである。而して此 の研磨面は砂岩に作られ，又其の表面の傾科を测つて見ると，北に $23^{\circ}$ 傾い て居る事が知られる。第40圖は此の研磨面をより近距離より撮影したるので あるが，現在風化破碎せられ，其の割れ方は稍ぬ格子狀になつて居り，其の 破碎岩片の大さは寫這中の鐵砲と比較して子知られる樣に， I5-30 $\mathrm{cm}$ 位の ものが多い。今此の岩面を仔細に觀察するに碎磨せられて居るのみならず, 水蝕による事明かな條痕が認められる事であつて夫れには，細く密なるるの そ，太く粗なるものとの2 種がある。而して此の條痕は赤銹の如き水酸化鐵 に染められて居り，一見して最近の形成に係るものでなく，古い時代のもの である事が明かである。筆者は此の岩面の一部を自然の状態に於て割れた睢 標本として持ち歸つたが, 夫れを拓本に取つたるのが第48圖にに示するのであ 
る。之れによつても見られる樣に, 此の地點の岩面々長方形に割れる事が多 い。以上の觀察によつても明かなる如く次高北峯, タラクッシャ山間の山稜

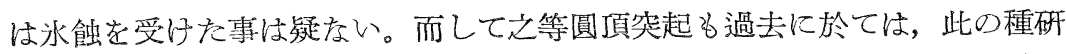
磨面に被はれ，從つて圓頂突起水蝕によつて形成されたものである事は議 論の餘地がない樣に思はれるが，如何にして此の種の形態を表すに至つたか に就ては後章に於て考察する事にしたい。

此の山稜上に於て侗注意す可きは, Errattic blockと思はれるものが諸處に 殘つて居る事である。其の多くは破碎せられて居るが，極く稀な場合に於て 其の原形を保つて居る事がある。郎ち第39圖は其の一例であるが（其の大さ は傍に立つタイヤル族蕃人と此較せられたい), 此の場合に於て子寫眞に見ら れる樣に此の大塊を爾斷する割れ目が 2 ケ處認められる。見樣によつては此 の大岩は山稜上の岩磐に續いて居る樣にも見えるが，仔細に之れを觀察する 時は之れは全くの轉位した岩塊である事が知られる。而して堅硬な砂岩より 成る此の岩塊の表面には現在削痕を認㧹ないが，其の表面は全體上下面共 に極好圓滑に研磨せられ，氷蝕に關係あるを感ぜしめる。斯くの如き狹き 山稜上に Erratic block の見出される事は餘り例のない事實の樣に思はれる が，過去に於てより廣き山棱を想像すれば解し難い事でもない樣に思はれる。 此のErratic block に就ては再查の䁱再び論ずる事にしたい。

(2间目の終り，4司にて完結の豫定). 